УДК 378.4:005.336.2(73)

DOI:10.15330/esu.14.7-12

\section{Тетяна Горохівська,}

кандидат педагогічних наук, доцент,

Національний університет "Львівська політехніка"

(м. Львів, Україна)

Tetyana Horokhivska,

Candidate of pedagogic sciences ( $\mathrm{PhD})$,

Associate Professor, Lviv Polytechnic National

University (Lviv, Ukraine)

t.gorohivska@gmail.com

\title{
РОЗВИТОК ПРОФЕСІЙНО-ПЕДАГОГІЧНОЇ КОМПЕТЕНТНОСТІ ВИКЛАДАЧІВ ВИЩОї ШКОЛИ У КОНТЕКСТІ ДОСВІДУ США
}

\section{DEVELOPING OF PROFESSIONAL PEDAGOGICAL COMPETENCY OF LECTURERS IN THE CONTEXT OF THE USA EXPERIENCE}

У статті розглянуто тенденчії розвитку професійно-педагогічної компетентності викладачів вищої иколи у контексті досвіду США. Окрему увагу приділено аналізу науковопедагогічної літератури, присвяченої проблемі розвитку професійно-педагогічної компетентності педагогічних працівників США. Наголоиено, иро професійно-педагогічна компетентність займас найважливіме місче серед основних компетентностей викладачів вицой иколи, оскільки безпосередньо пов'язана з виконанням професійних обов'язків. Виявлено особливості професійного розвитку викладачів американських вищих навчальних закладів, серед яких визначальне місие займає система підвищення кваліфікації педагогічних прачівників. Визначено нормативну основу, проаналізовано бази, різноманітні форми $і$ програми підвищення кваліфікації й удосконалення професійно-педагогічної компетентності викладачів вищої иколи у СШАА.

Ключові слова: професійно-педагогічна компетентність, викладач вищої иколи, професійний розвиток, система підвищення кваліфікації, США.

The article deals with the trends in developing professional pedagogical competency of lecturers in the context of the US experience. Specific attention is paid to analyzingscientific pedagogical literature devoted to the problem of developingprofessional pedagogical competency of teaching faculty in the USA.It is specified that professional pedagogical competency of the lecturer is considered by experts as his/her basic characteristic, which consists of the five main aspects: general outlook; basic skills; the knowledge of the subject he/she teaches; the knowledge of pedagogy, psychology and philosophy; pedagogical mastery.It is emphasized that professional pedagogical competency occupies the most important place among the main competencies of the lecturer as it is directly related to performing professional duties. The system of advanced training for teaching faculty is rather important in the context of American lecturers' professional development. The legal basis of advanced training and professional development of teaching faculty in the system of the US postgraduate education is determined. The bases, various forms and programmes for professional development and enhancement of professional pedagogical competency of the lecturer are analyzed. It is concluded that the development of professional pedagogical competencyof the lecturer in the United States is determined by a dynamic, multifaceted and meaningful interpersonal process, resulting in the changes in his/her consciousness, self-awareness, intellectual, motivational, emotional, volitional and active spheres, life and professional positions; that is there occurs a holistic professional self-development. 
Key words: professional and pedagogical competency, teacher of higher educational establishment, professional development, system of training, the USA.

Постановка проблеми. Сучасна вища освіта, перебуваючи в процесі оновлення та інтеграції у європейський та світовий освітній простір, вимагає якісного зростання потенціалу викладача. Сьогодні вища школа потребує конкурентоспроможного, компетентного працівника, шо орієнтується у інноваціях педагогічної науки, здатного до активної роботи на рівні світових стандартів, спроможного до постійного професійного зростання, готового змінюватись, творчо та конструктивно працювати в нових соціально-економічних реаліях. За цієї умови інструментарієм становлення нової генерації освітян виступає розвиток їх професійно-педагогічної компетентності, а одним із шляхів успішної реалізації підвищення професіоналізму викладачів - вивчення $\mathrm{i}$ врахування зразків зарубіжного досвіду вдосконалення означеної компетентності.

Аналіз останніх досліджень і публікацій доводить, що особливості зарубіжних систем педагогічної освіти, професійної підготовки викладачів у розвинених країнах світу знайшли відображення у різних дослідницьких напрямах і аспектах. Так, вивчення зарубіжного досвіду 3 професійно-педагогічної підготовки освітян вишої школи і творче використання його конструктивних ідей в процесі оновлення вітчизняної системи неперервної педагогічної освіти стало предметом досліджень вітчизняних науковців, серед яких - Н. Авшенюк, Л. Дяченко, О. Овчарук, О. Огієнко, Л. Пуховська та ін. Зокрема, проблемі підготовки вчителів у Великій Британії належать дослідження Д. Медведовської, О. Чорної, Н. Яцишиної та ін.; система післядипломної педагогічної освіти у Франції вивчалася В. Лащихіною, Т. Левченко, Н. Постригач та ін.; особливості організації системи вищої педагогічної освіти в Німеччині студіювали В. Базова, І. Бойчевська, В. Гладуш, Л. Дяченко та ін.; сутність системи освіти скандинавських країн, Фінляндії, Бельгії досліджували Н. Андрійчук, Н. Базелюк, Ю. Закаулова Т. Грабовська, К. Ковтун, А. Роляк та ін. Лише окремі роботи присвячені проблемі організації професійного розвитку педагогічних працівників в системі післядипломної освіти зарубіжних країн, серед таких на особливу увагу заслуговують праці В. Олійника, С. Катунської, Г. Капосльза, Н. Клясена та С. Синенка.

Водночас, різні аспекти професійного розвитку, проблеми професійно-педагогічної компетентності викладачів у США висвітлюються у роботах таких науковців, як І. Зварич, М. Красовицький, В. Лунячек, Н. Мукан, Н. Приходькіна, О. Романовський, С. Степаненко, О. Стойка та ін. Значний науковий інтерес становлять праці дослідників США, присвячені питанням способів підвищення рівня професійної підготовки педагогів та їх компетентності (К. Вайнштайн, К. Ейбел, М. Шеппард Ноулс, Дж. Равен, Річард А. Свенсон, П. Селдін, Л. Спенсер, С. Спенсер, Е. Хотон та ін.).

Виокремлення раніше не вирішеної частини. Незважаючи на те, що кількість публікацій, присвячених дослідженню зарубіжних систем педагогічної освіти, особливостей професійного розвитку викладачів вищої школи, впровадження досвіду розвинених країн світу з професійної педагогічної підготовки, постійно зростає, доводячи поглиблення науково-педагогічної уваги до цього перспективного напряму, проблема розвитку професійно-педагогічної компетентності викладачів вищої школи у США до останнього часу не знайшла достатнього наукового обгрунтування.

Формулювання цілей статті. Метою статті визначено здійснення аналізу тенденцій розвитку професійно-педагогічної компетентності викладачів вищої 
школи у контексті досвіду США. Виокремлено наступні завдання: проаналізувати науково-педагогічну літературу, присвячену проблемі розвитку професійнопедагогічної компетентності педагогічних працівників США; виявити особливості професійного розвитку викладачів американських закладів вищої освіти.

Виклад основного матеріалу. Нині значний науковий інтерес становлять прогресивні здобутки країн, що демонструють високий рівень професійної підготовки і розвитку викладачів відповідно до світових стандартів, мають багаті історичні традиції освіти, накопичили значний досвід у галузі підготовки освітян у нових соціокультурних умовах [1, с. 5]. Освітні системи Великої Британії, США, Німеччини, Франції, Австрії, Нідерландів, Канади характеризуються значними здобутками 3 питань якісної професійної підготовки викладачів. В них “науково обгрунтовано, практично перевірено i ретельно відпрацьовано... комплекс викладацьких умінь і компетентностей педагогів” [3, с. 77].

Актуальним для сучасного оновлення системи освіти України $\epsilon$ досвід розвитку професійно-педагогічної компетентності викладачів вищої школи, накопичений в США. Він містить шляхи підвищення якості даної компетентності, шо передбачають перепідготовку викладачів, спрямовану на ефективний пошук актуальних знань, умінь і навичок, оптимізацію моральної та психологічної готовності до професійної діяльності у закладах вищої освіти.

Слід зазначити, що теоретичні і практичні дослідження проблеми професійнопедагогічної компетентності викладачів у США широко представлені в науковопедагогічній літературі [2]. Так, М. Ноулс (M. Knowles) стверджує, що нагальним завданням вищої освіти сьогодні $\epsilon$ підготовка таких педагогів, для яких найважливішою компетенцією була 6 здатність до постійного самонавчання протягом життя, і визначальним умінням - уміння застосовувати свої знання в умовах, шо змінюються [11].

Суголосною є думка американських дослідників Л. і С. Спенсер (L.M. Spencer, S.M. Spencer), які розглядають професійно-педагогічні компетентності викладача як його базові характеристики, що обумовлюють ефективність виконання ним діяльності, рівень якої визначається конкретними критеріями для роботи у вищій школі [13]. Якостями, що виступають підгрунтям означених компетентностей, науковці означають психофізіологічні властивості, мотиви, Я-концепцію, знання та уміння.

Окрему увагу особливостям професійно-педагогічної компетентності американських педагогів приділяє М. Ірот (А.M. Eraut). У своїй роботі [9] до таких особливостей автор відносить активне впровадження альтернативних форм та програм навчання, які передбачають гнучкість умов професійного зростання, забезпечують індивідуальні потреби, сприяють неперервному професійному розвитку та відповідають реаліям педагогічної практики вищої школи. В ході визначення професійно-педагогічних компетентностей, M. Ірот підкреслює їх загальний характер і більш широке розуміння у порівнянні з кваліфікованістю працівника [10].

3 точки зору експертів США у складові професійно-педагогічної компетентності, як вимоги до педагогічних працівників, закладені п'ять головних аспектів: загальний кругозір; основні вміння; знання предмету, що викладається; знання з педагогіки, психології і філософії; майстерність викладача [14]. Водночас, американські педагоги К. Ебл і В. Маккічі (К. E. Eble, W. J. McKeachie) вважають, що розвиток професіоналізму викладача вищої школи припускає поглиблення його знань у галузі теорії навчання, вдосконалення професійних умінь і навичок, 
становлення професійної свідомості й педагогічної спрямованості його особистості, усвідомлення необхідності постійного самовдосконалення [8].

Як зазначають науковці [6], останнім часом в США у практику вводяться експерименти, основною метою яких стає зміна методів і форм розвитку професійно-педагогічної компетентності викладачів вищої школи. Спрямованість подібних експериментів в університетах США зводиться до спроби змінити традиційну модель “професор, який говорить, - студент, який слухає” таким чином, щоб змістити акцент діяльності викладача 3 традиційних пасивних форм проведення навчання (лекція, семінар) на більш активні види самостійної індивідуальної роботи. Беручи до уваги той факт, що поява комп'ютерів, Інтернету відкрила доступ до численних наукових джерел інформації, стає зрозумілим, що використання традиційної лекції, як домінуючої форми навчання, перестало влаштовувати як самих студентів, так і викладачів. У цьому контексті варто згадати позицію дослідника П. Селдіна (Peter Seldin), який, обгрунтовуючи основні компоненти поняття "ефективне викладання", назвав їх загальновизнаними - глибоке знання предмета, чітка презентація матеріалу, активне залучення студентів у навчальний процес, мотивація їх пізнавальної активності тощо [12].

Варто зазначити, що в системі підвищення кваліфікації викладачів вищої школи США поширився рух "Розвиток професорсько-викладацького складу" (Faculty Development Programs). Підгрунтям цього руху стали об'єктивні причини, серед яких - недоліки традиційної методики викладання, несформованість професійно-комунікативної компетентності, розширення потреб студентів. В рамках означеного руху діяльністю з підвищення кваліфікації викладачів займаються сотні коледжів і університетів на добровільній основі. Підтвердженням цьому є той факт, що вже у 1988 р. слухачем програм професійного вдосконалення та кваліфікаційної підготовки був кожен третій громадянин США [7, с. 26]. Основними формами роботи в спеціальних підрозділах чи установах закладів вищої освіти визначаються семінари; методичне керування новими або молодшими викладачами; конференції 3 питань удосконалення університетської освіти тощо.

Нормативною основою підвищення кваліфікації та професійного розвитку педагогів в системі післядипломної освіти США виступають національні стандарти, розроблені у 2001 р. Американською національною радою з розвитку персоналу США (National Staff Development Council) [4, с. 103]. Саме вони визначають зміст, види та форми підвищення кваліфікації викладачів.

До загальнонаціональних центрів, метою яких $\epsilon$ координація діяльності педагогічної громадськості США з питань підвищення кваліфікації, створення і реалізація програм професійно-педагогічної підготовки викладачів сьогодні належать:

- Американська асоціація вищої освіти (American Association of Higher Education);

- Асоціація американських коледжів i університетів (Association of American Colleges \& Universities);

- Рада аспірантських шкіл (Council of Graduate Schools) та ін. професійні організації.

Зміст професійного розвитку педагогів охоплює проблеми прозорості освіти; якості викладання; об'єктивності оцінювання; співпраці учасників освітнього процесу; створення можливостей для вивчення основних механізмів залучення громадськості до роботи навчального закладу з метою покращення освітнього процесу [4, с. 104].

Серед форм підвищення кваліфікації педагоги-експерти [9] виокремлюють різноманітні курси (денні/вечірні; очні/заочні; довгочасні/короткочасні; суботні/не- 
дільні; з відривом/без відриву від роботи, літні/міжсеместрові тощо), які провадять свою діяльність при наукових центрах і консультаційних фірмах за програмами теоретичного і практичного спрямування.

Водночас, українська дослідниця Н. Приходькіна у своїй роботі [5] розглядає наступні форми підвищення кваліфікації і розвитку професійно-педагогічної майстерності викладача вищої школи США:

- орієнтаційні конференції для молодих викладачів (The New Faculty Orientation Program);

- семінари із загальнотеоретичних питань педагогіки вищої школи, психології освіти дорослих, традиційних та інноваційних методів викладання тощо;

- майстерні (workshops), які поєднують елементи педагогічної теорії і практики;

- індивідуальні консультації педагогів, психологів і соціологів 3 проблем викладання;

- інтерактивні дискусії і “Круглі столи” викладачів та аспірантів зі специфічних проблем навчання;

- взаємовідвідування (відеозапис навчальних занять) 3 наступним аналізом відвіданих занять (reciprocal visits and observations);

- організація індивідуалізованого наставництва (mentoring);

- складання викладацького досьє (portfolio) для оцінки діяльності викладача i власного самоаналізу і самооцінки;

- організація канікулярних мікроциклів “літніх шкіл” (summer schools), "інститутів" (institute on college teaching) з питань викладання у вищій школі;

- конференції (загальнонаціональні, регіональні, між закладами освіти тощо) для різних категорій працівників.

Висновки. Вивчення тенденцій розвитку професійно-педагогічної компетентності викладачів вищої школи у контексті досвіду США дало можливість засвідчити, що ця практика формується з урахуванням економічних, політичних та соціокультурних особливостей. Аналіз науково-педагогічної літератури довів, що розвиток професійно-педагогічної компетентності американського викладача вищої школи визначається динамічним, багатогранним і змістовним внутрішньоособистісним процесом, в результаті якого відбуваються зміни в його інтелектуальній, мотиваційній, емоційно-почуттєвій, вольовій та діяльнісній сферах, життєвих і професійних позиціях

Перспективи подальших наукових розвідок полягають у вивченні канадського досвіду розвитку професійно-педагогічної компетентності викладачів вищої школи.

\section{Література}

1. Зарубіжний досвід професійної підготовки педагогів : аналітичні матеріали / Авшенюк Н.М., Дяченко Л.М., Ковтун К.В., Марусинець М.М., Огієнко О.І., Сулима О.В., Постригач Н.О. Київ: ДКС “Центр”, 2017. - 83 с.

2. Зварич І.М. Теоретичні й практичні дослідження проблеми педагогічної компетентності викладачів у науково-педагогічній літературі США / І.М. Зварич // Педагогіка і психологія. Вісник АПН України. - Київ, 2011. - № 2 (71). - С. 98-104.

3. Компетентнісний підхід до підготовки педагогів у зарубіжних країнах: теорія та практика: монографія / Н.М. Авшенюк, Т.М. Десятов, Л.М. Дяченко, Н.О. Постригач, Л.П. Пуховська, О.В. Сулима. - Кіровоград: Імекс-ЛТД, 2014. - 280 с.

4. Нісімчук А.С. Сучасні педагогічні технології: Навч. посібник / А.С. Нісімчук, О.С. Падалка, О.Т. Шпак. - К. : Просвіта, 2000. -368 с.

5. Приходькіна Н. Особливості професійно-педагогічної підготовки викладача вищої школи США у системі підвищення кваліфікації / Н. Приходькіна // Нова педагогічна думка. - 2013. № 3, C. 115-118. 
6. Стойка О.Я. Деякі особливості розвитку системи вищої освіти в США і професійної підготовки фахівців / О.Я. Стойка // Науковий вісник Ужгородського університету : Серія: Педагогіка. Соціальна робота / гол. ред. І. В. Козубовська. - Ужгород: Говерла, 2013. - Вип. 27. - C. 199- 201

7. Carnevale A.P. The Learning Enterprise / Antony P. Carnevale // Training and Development Journal, 1989. - February. - P. 26-33.

8. Eble K. E. Improving Undergraduate Education Through Faculty Development / K.E. Eble, W.J. McKeachie. - San Francisco : Jossey-Bass, 1986.

9. Eraut A.M. Developing professional knowledge. New paradigms and practices in Professional development. - New York: Teachers College Press. - 1995. - P. 227-252/

10. Eraut M. Development Professional Knowledge and Competence / M. Eraut. - London: Falmer Press, 1994. - $164 \mathrm{p}$.

11. Knowles Malcolm S., Hoton Elwood F., Swanson Richard A. The Adult Learner: The Definitive Classic in Adult Education and Human Resource Development (Managing Cultural Differences). // 5th ed., Houston, TX: Gulf Publishing Company, 1998. -P. 113-122.

12. Seldin P. Successful Uses of Teaching Portfolios / P. Seldin. - Bolton M.A. : Anker, 1993.

13. Spencer L.M. Competence at Work: Models for Superior Performance / L.M. Spencer, S.M. Spencer. - New York: John Wiley \& Sons, NY. - 1993. - 385 p.

14. Weinstein C.E. The teaching of learning strategies. In M.C. Wittrock. (Ed.) Handbook of research on teaching / C.E. Weinstein, R.E. Mayer. - New York: Macmillan, 1996.-P. 315-327.

\section{References}

1. Avsheniuk, N.M., Diachenko, L.M., Kovtun, K.V., Marusynets, M.M., Ohienko, O.I., Sulyma, O.V., Postryhach, N.O. (2017). Zarubizhnyi dosvid profeciinoi pidhotovky pedahohiv.: analitychni materialy [Foreign experience of professional training of teachers:analytical materials], DKS Tsentr, Kyiv, Ukraine, $83 \mathrm{p}$.

2. Zvarych, I.M. (2011). "Theoretical and practical researches of the problem of pedagogical competence in the scientific-pedagogical literature of the USA", Pedahohika i psykholohiia. Visnyk APN Ukrainy, no. 2 (71), pp. 98-104

3. Avsheniuk, N.M., Desiatov, T.M., Diachenko, L.M., Postryhach, N.O., Pukhovska, L.P., Sulyma O.V. (2014). Kompetentnisnyi pidkhid do pidhotovky pedahohiv u zarubizhnykh krainakh: teoriia ta praktyka [Competency approach to teachers training in foreign countries: theory and practice], monograph, Imeks-LTD, Kirovohrad, Ukraine, $280 \mathrm{p}$.

4. Nisimchuk, A.S., Padalka, O.S., Shpak, O.T. (2000). Suchasni pedahohichni tekhnolohii [Modern pedagogical technologies], tutorial, Prosvita, Kyiv, Ukraine, $368 \mathrm{p}$.

5. Prykhodkina, N. (2013) "Features of professional and pedagogical training of lecturers in the USA in system of training", Nova pedahohichna dumka, no. 3, pp. 115-118.

6. Stoika, O.Ya. (2013). "Some peculiarities of the development of the system of higher education in the USA and professional training of specialists", Naukovyi visnyk Uzhhorodskoho universytetu, no. 27, pp. 199-201.

7. Carnevale, A.P. (1989). The Learning Enterprise. - Training and Development Journal - February.

8. Eble, K. E. (1986). Improving Undergraduate Education Through Faculty Development. - In W.J. McKeachie (Ed.). - San Francisco : Jossey-Bass

9. Eraut, A.M. (1995). Developing professional knowledge. New paradigms and practices in Professional development. - New York: Teachers College Press.

10. Eraut, M. (1994). Development Professional Knowledge and Competence. - London: Falmer Press.

11. Knowles, Malcolm S. (1998). The Adult Learner: The Definitive Classic in Adult Education and Human Resource Development (Managing Cultural Differences). - In Hoton, Elwood F., Swanson, Richard A. (Eds.), Houston, TX: Gulf Publishing Company.

12. Seldin, P. (1993). Successful Uses of Teaching Portfolios. - Bolton M.A.: Anker.

13. Spencer, L.M. (1993). Competence at Work: Models for Superior Performance. - In S.M. Spencer (Ed.). - New York: John Wiley \& Sons, NY.

14. Weinstein C.E. (1996). The teaching of learning strategies. - In M.C. Wittrock, R.E. Mayer. (Eds.) Handbook of research on teaching. - New York: Macmillan. 